\title{
Eső hatása a Csorsza-patak vízgyüjtőjének téli hidrológiai folyamataira
}

\author{
${ }^{1}$ Horel A., ${ }^{1}$ BaKacsi Zs., ${ }^{1}$ Dencsö M., ${ }^{1,2}$ FARKAS Cs., ${ }^{1}$ Gelybó Gy., ${ }^{1}$ KÁSA I., \\ ${ }^{1}$ Tóth E., ${ }^{1}$ MOLNÁr S., ${ }^{1}$ KoÓs S. \\ ${ }^{1}$ MTA ATK Talajtani és Agrokémiai Intézet \\ ${ }^{2} \mathrm{NIBIO}$, Norwegian Institute of Bioeconomy Research
}

\section{Bevezetés}

A klímaváltozással összefüggésben felmerülő egyik legtöbbet említett kihívás a szélsőséges időjárási helyzetek gyakoriságának várható megnövekedése (IPCC, 2007; FARKAS et al., 2014; FAŠKO et al., 2008). A szélsőséges csapadékesemények gyakoriság változásának megfigyelésén alapuló kutatások limitáltak, a megfigyelések korlátozott elérhetősége miatt (ALEXANDER, 2016). Olyan területeken azonban, ahol ilyen megfigyelések kellő gyakorisággal és térbeli lefedettséggel elérhetők, számos kiemelkedő eredmény született (KLEIN TANK \& KÖNNEN, 2003; LAKATOS et al., 2007; KeGGENHOFF et al., 2014). A jövőben várható trendet tekintve a klímamodellek nagy része az intenzív esőzések gyakoriságának növekedését mutatja. Ez várhatóan hatással lesz többek között a mezőgazdasági termőföldek eróziós kitettségére, érzékenységére is (ZIADAT \& TAIMEH, 2013), azaz felerősödő talajeróziós folyamatokkal kell számolni. A talaj szerkezete különösen érzékeny a különböző éghajlati és területhasználati változásokra, valamint erősen befolyásolja a talaj vízgazdálkodását (FARKAS et al., 2014; HOREL et al., 2015b; KAY, 1990).

A különböző módon művelt talajokon történő víz- és tápanyagmozgásnak jelentős hatása van a termesztett növények fejlödésére, illetve a termés mennyiségére és minőségére (HOREL et al., 2015a). A nem megfelelő agrotechnikai beavatkozások a tápanyagok kimosódását vagy felszíni lefolyás megnövekedését eredményezhetik, s ezek jelentősen befolyásolják a talajban lévő mikrobiális közösségek összetételét (CRUZ-MARTINEZ et al., 2009), a felszíni és felszín alatti vizek minőségét (FARKAS et al., 2013; LICHNER et al., 2013), ezáltal a növénytermesztés hatékonyságát, gazdaságosságát.

A talajdegradáció mértékét nagyban meghatározza a növényborítottság és a talajmüvelés, hiszen ezek közvetett hatással vannak a talajfelszínt elérö vízcseppek kinetikus energiájának nagyságára (BRANDT, 1989), befolyásolva a talajszemcse elmozdítását, a szemcsetranszport és a szemcseelválás folyamatait (KERÉNYI, 1984, 1986; MORGAN, 1978; RAJKAI, 2012). A növényzet típusa különösen fontos szerepet játszik az egységnyi talajfelszínre jutó csapadék mennyiségének, valamint az esőcseppek átlagos méretének alakításában (MOHAMMAD \& ADAM, 2010; MORGAN \& DUZANT, 2008). Habár a növénytakaró összes felületének nagysága a téli időszakban a levélzet hiánya miatt alacsonyabb, a növényi szárak és ágak ekkor

Postai cím: BAKACSI ZsóFIA, MTA ATK Talajtani és Agrokémiai Intézet,1022 Budapest, Herman Ottó út 15.

E-mail: bakacsi.zsofia@agrar.mta.hu 
is jelen vannak, sőt a gyepek esetében a száraz és félig zöld növényi részek télen is megtalálhatóak. Erdőben, a lombkorona miatt a törzsről lecsurgó csapadék a nyári időszakban nem jelentős, de télen a lehulló eső körülbelül 5\%-át teszi ki (DOLMAN, 1987). Ez a mennyiség a csapadékintenzitás függvényében is változik (XIAO et al., 2000), ezért a talajfelszínre jutó áthulló csapadék mennyiségét a növényzet mellett az esőesemény tulajdonságai, valamint a talajtakaró típusa és vastagsága is befolyásolják, például az erdőkben képződött avartakaró nagyban csökkenti az esőcseppek erozív hatását, így talajvédő szerepet tölt be (SHAXSON \& KASSAM, 2015). Az átlagos esőcseppátmérő az esőzés intenzitása és a hőmérséklet függvényében változik. A nagyobb intenzitású csapadékesemény következtében a cseppátmérő növekszik, amíg az esőcsepp el nem ér egy olyan méretet, ahol az esőcseppek fizikai hatások következtében kettéválnak (PILCH \& ERDMAN, 1987).

A talaj nedvességtartalma az időjárási viszonyok (csapadék, melegedés stb.) függvényében folyamatosan változik, azonban az aktuális talajnedvesség-tartalmat egyéb tényezők is befolyásolják, melyek közül kiemelendőek a talaj hidrológiai tulajdonságai (pl. a vízvisszatartó- és vízvezető képessége), illetve a földhasználat. A növényi vízfogyasztás (transzspiráció) a talaj vízmérlegének egy meghatározó, és nehezen mérhető eleme, melynek aktuális értéke függ a növényzet jellegétől és növekedési fázisától is (CsORBA et al., 2011; LIU et al., 2011; RAJKAI, 1988).

A felszíni és felszín alatti víztestek minőségének megóvása érdekében szükséges a hidrológiai és az eróziós folyamatok minél pontosabb ismerete, valamint a klímaváltozás, vagy a földhasználatváltás lehetséges káros hatásait mérséklő megoldások keresése. A Balaton régió hazánk kiemelt nemzetgazdasági és természeti értéke. A hirtelen történő, nagy intenzitású csapadékhullás következtében a Balaton vízgyüjtőjében található patakokból megnövekedett mennyiségű lebegtetett hordalék jut a Balatonba, aminek eredményeként biogeokémiai változások történnek, mind a vízben, mind annak környezetében (NGUYEN et al., 2005). A talaj és a víztest együttes tanulmányozása elősegíti az anyagforgalom és a szárazföldi- és vízi ökoszisztéma teljesebb megismerését.

A mezőgazdasági területek területhasználati formáinak változása következtében megváltozhat a Balatonba jutó talajhordalék mennyisége is (JORDÁN et al., 2005; SZILASSI et al., 2006). A Balaton és környékének vízi, illetve szárazföldi ökoszisztémáinak és talajai minőségének megőrzése érdekében elengedhetetlen a vízgyüjtő terület talajeróziós folyamatainak ismerete. Számos tanulmány számol be arról, hogy adott vízgyüjtőn a kiindulási talajnedvesség jelentősen befolyásolja a lefolyást és lebegtetett hordalék mennyiségét egy-egy csapadékesemény alkalmával (MEDEIROS et al., 2010; CASTILLO et al., 2003; MÜLLER et al., 2006).

A jelen tanulmányban bemutatott vizsgálat célja a különböző felszínborítottságú területeken a téli időszakhoz tartozó nagyobb talajnedvességtartalom mellett, egy nagyobb csapadékeseményt követően a vízgyüjtőterületről lefolyó lebegtetett hordalékmennyiségek alakulásának megfigyelése volt. 


\section{Vizsgálati anyag és módszer}

\section{A vizsgálati terület jellemzése}

A Veszprém megyei Csorsza-patak, melynek vízgyüjtő területe ökológiai szempontból különösen fontos (STENGER-KovÁCs et al., 2008; SzIVÁK \& MóRA, 2009), vízhozamával a Balaton vizét táplálja, zánkai befolyással. A terület mezőgazdasági (főként borászati) és turisztikai szempontból is kiemelt jelentőségü. $\mathrm{Az}$ általunk vizsgált terület a Zánka-Tagyon-Szentantalfa által határolt részvízgyüjtő (1. ábra), melynek területe $21,3 \mathrm{~km}^{2}$, ebböl $29,7 \%$ erdő, $29,7 \%$ ültetvény (jellemzően szőlö), 16,9\% gyep és cserjés, 12,8\% szántó, 5,7\% legelö és 5,1\% település (CORINE, 2006). A kistáj éghajlata a Balatonhoz közeli területeken mérsékelten meleg, ahol az évi napfénytartalom 1970-2000 óra, az évi középhőmérséklet $9,5-9,7^{\circ} \mathrm{C}$, az évi csapadékösszeg $600 \mathrm{~mm}$, a hótakarós napok száma 35-40, és az átlagos szélsebesség $3 \mathrm{~m} / \mathrm{s}$ körüli (DÖVÉNYI, 2010). Szentantalfa és Balatoncsicsó környezetében többnyire vályog fizikai féleségü, (esetenként visszameszeződött) barnaföldek és agyagbemosódásos barna erdőtalajok a jellemzök (DöVÉNYI, 2010), kisebb foltokban földes kopárok találhatók.

\section{Alapvizsgálatok}

A talajnedvesség- és a hőmérséklet adatok monitorozása négy helyszínen (erdő; gyep; szőlő 2015. november 4-től; őszi búzával vetett szántó 2015. november 19-től 2016. március 1-ig), az adott talajra előzetesen kalibrált Decagon 5TM szondákkal történt. A szondákat három mélységben helyeztük el, 15, 40 és $70 \mathrm{~cm}$ rel a talajfelszín alatt, melyek egy Decagon Em50 adatgyüjtőhöz kapcsolva gyüjtötték az adatokat 10 perces gyakorisággal. A gyep esetében - ahol erősen köves az altalaj- megvalósíthatósági okból két mélységben, 15 és $40 \mathrm{~cm}$ mélyen telepítettuik a szondákat. A talajnedvesség- és hőmérsékletmérő szondák helyszíneit a vízgyüjtőterületre jellemző földhasználati és lejtésviszonyok figyelembe vételével választottuk ki, így a kiválasztott négy terület a vízgyüjtő több, mint $80 \%$-át reprezentatívan lefedi földhasználati szempontból (DöVÉNYI, 2010). A szőlő, a gyep és az erdős mintaterületek a szántóhoz viszonyítva magasan helyezkednek el (szőlö: 269,7 m, gyep: 282,2 m, erdő: 284,4 m tengerszint feletti magasságban), 5$15 \%$ közötti lejtésekkel. A szántó 0-5\%-os lejtőviszonyokkal a vízgyüjtő terület alacsonyabban fekvő pontján helyezkedik el, 220,1 m tengerszint feletti magasságban. Annak érdekében, hogy reprezentatív képet alkossunk az egyes felszínhasznosítási típusok nedvességforgalmáról, az arra legjellemzőbb lejtési viszonyú területet jelöltünk ki monitoring pontnak. 


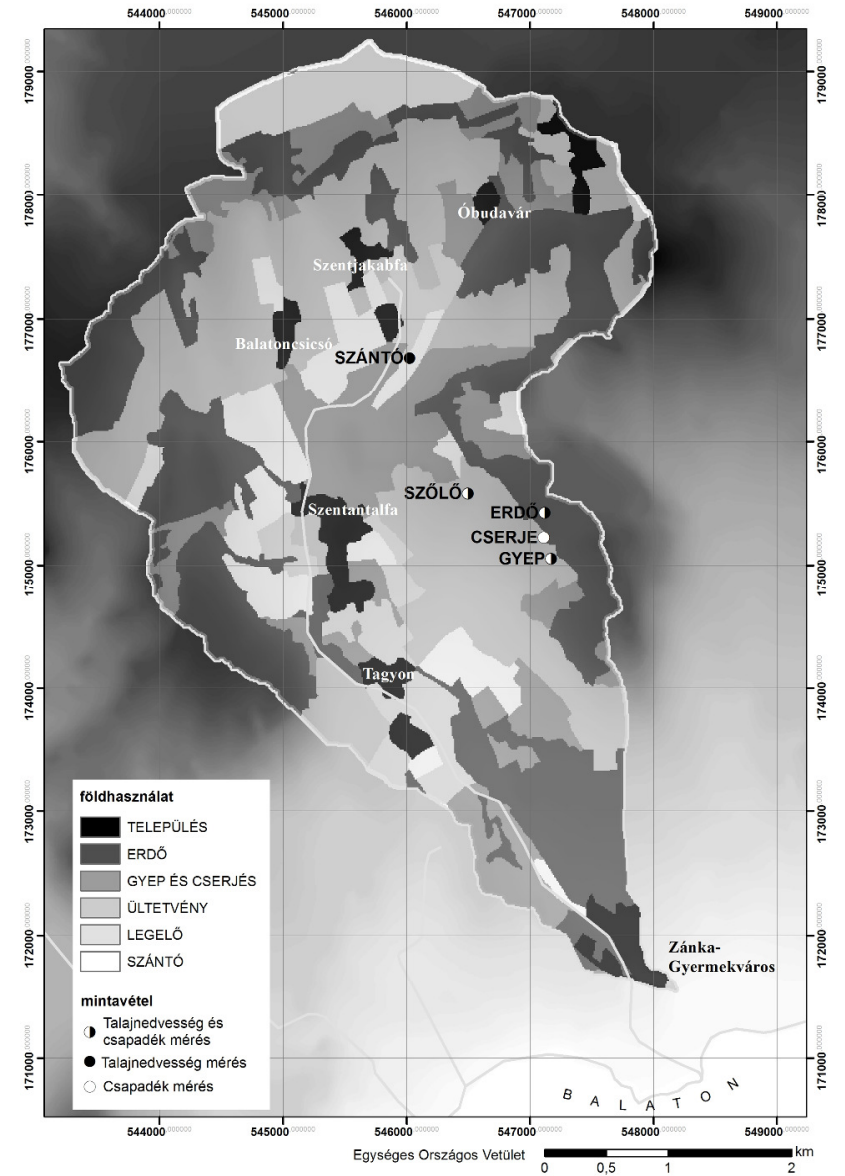

\section{1. ábra}

A Balaton-felvidéki Csorsza vízgyüjtő mintaterület (Zánka, Tagyon, Szentantalfa és környéke) földhasználati viszonyai és mintavételi helyek (forrás: CORINE, 2006).

A négy kísérleti mintaterületen 2016. január 14-én a talaj felső 2-10 cm-es rétegéből vett talajmintákból fizikai és kémiai alapvizsgálatokat végeztünk: szemcseösszetétel (MSz-08-0205-1978, pipettás módszer), pH (MSz-08-0206/21978), karbonát (MSz-08-0206/2-1978, kalciméteres módszer) és szerves széntartalom (MSz-08-0210:1977, Tyurin módszer; 1. táblázat). A talajmintákat területenként három ismétlésben, pontmintában gyüjtöttuik. A mintavételi és a monitoring helyszínek elhelyezkedését a vízgyüjtőn belül az 1 . ábra szemlélteti, ahol a szőlö, a gyep és az erdő esetében a mintavételi és monitoring pontok megegyeözek (1. ábra).

A vízmintavétel a Csorsza-patak zánkai részénél történt (EOV: 547799, 171763). A vízmintákat egyliteres múanyag edényekbe gyüjtöttük, amiket a mintavétel előtt minimum háromszor átöblítettünk a patak vizével. A vízmintavétel 
eseménymentes időszakban naponta, míg nagyobb esőzés ideje alatt az első hat órában óránként, utána kétóránként történt, 42 órán keresztül (összesen 24 vízmintát gyüjtöttünk).

A csapadékintenzitást a szőlővel hasznosított mintaterületen, az ott elhelyezett talajszenzorok környékén, egy 2 m magasságban elhelyezett Decagon $\mathrm{ECH}_{2} \mathrm{O}$ Rain (model ECRN-50) csapadékmérő rögzítette $1 \mathrm{~mm}$ pontossággal. Az automata csapadékmérő müszer mellett négy vizsgált területen (gyep, szőlő, erdő és cserjés) egy-egy mủanyagból készült, $19,63 \mathrm{~cm}^{2}$ felületủ és $5 \mathrm{~cm}$ magasságú csapadékgyüjtő edényt is kihelyeztünk, két-két ismétlésben, hogy a potenciálisan áthulló csapadék mennyiségét is össze tudjuk hasonlítani területenként. A gyepes területen az edényeket a növényzet fölé helyeztük, így azokat az adatokat kontrollként (teljes lehulló esőmennyiség) kezeltük, és a többi területen lehullott (áthulló) esőmennyiséget az itt mértekhez viszonyítottuk. A szántó területén nem vizsgáltuk az áthulló csapadék mennyiségét, helyette a gyep mellett található cserjésben folytattunk méréseket. A kísérlet végeztével meghatároztuk a csapadékgyüjtö-edényekben összegyüjtött esővíz mennyiségét és pH értékét (2. táblázat).

Az átlagos esőcsepp átméröt $\left(D_{50}\right)$ a következő egyenlet alapján becsültük (ZANCHI \& TORRI, 1980):

$$
D_{50}=\alpha R^{\beta}
$$

ahol a $D_{50}$ értékek mm-ben, míg az $R$ (csapadékintenzitás) mm/óra mértékegységben értendők a jelen tanulmányban óránkénti lebontásban mint teljes lehullott csapadékösszeg; $\beta$ konstans $(\beta=0,292)$. $\alpha$ értéke a hőmérséklet függvényében változik és a következő egyenlet alapján számolható (ZANCHI \& TORRI, 1980):

$$
\alpha=0,499 T^{0,225}
$$

ahol $T$ a mérés időpontjában mért léghőmérséklet ${ }^{\circ} \mathrm{C}$-ban.

A 2016. február 3-án történt nagyobb csapadékesemény során, 5 óra leforgása alatt a vízgyűjiő szentantalfai területére (mely magába foglalja az áthulló csapadék vizsgálatára kijelölt négy vizsgálati területet) $21,6 \mathrm{~mm}$ csapadék hullott, mely csapadékeseményt kampánymérés keretében bővebben vizsgáltuk. A lebegtetett hordalék mennyiségének becslése egy ProDSS modellü YSI típusú müszerhez kapcsolt zavarosságmérő szenzorral történt. A müszer kalibrálása 0,10 és 1000 FNU (Formazin Nephelometric Unit, Sigma-Aldrich) zavarossági standard oldatokkal történt. Az FNU (zavarossági) értékek és a vízben található lebegtetett hordalék mennyisége között egyenes arányosság van (RÜGNER et al., 2013), így a jelen tanulmányban megadott FNU adatokkal a Balatonba jutó lebegtetett hordalék mennyiségére is következtethetünk. A vízmintákat a patak $10 \mathrm{~cm}$-es mélységéig 
vettük, így az FNU értékek szempontjából a patak általi görgetett hordalékszállítást minimalizáltuk.

\section{Meteorológiai adatok}

A területre kihelyezett csapadékmérőn kívül az egyéb meteorológiai adatok, úgymint a napi maximum és minimum hőmérséklet, valamint a csapadékmennyiség egy közelben lévő meteorológiai állomásról származnak (Balatonederics, http://www.wunderground.com), és az átlagos cseppátmérők számítására használtuk.

\section{Vizsgálati eredmények és megvitatásuk}

\section{Általános vizsgálati eredmények}

A talajminták általános kémiai, valamint fizikai vizsgálati eredményeit és a mintavételi pontok földrajzi helyzetét a 1 . táblázat összegzi.

\section{1. táblázat.}

Talajtulajdonságok a különböző mezőgazdasági területeken, a 2-10 cm-es talajrétegből. $\Theta \Theta_{\mathrm{s}}^{-1}$ a talaj nedvességtartalma szaturáltság százalékában.

\begin{tabular}{|c|c|c|c|c|c|c|c|c|c|}
\hline & \multicolumn{3}{|c|}{$\begin{array}{l}\text { Szemcseösszetétel(3 frakció, } \\
\text { MSZ-08-0205:1978) (1) }\end{array}$} & \multirow[t]{2}{*}{$\underline{\underline{v}}$} & \multirow{2}{*}{$\begin{array}{l}0 \\
0 \\
ల \\
\%\end{array}$} & \multirow{2}{*}{$\begin{array}{c}\text { No } \\
\text { Un } \\
\mathrm{mS} / \\
\mathrm{cm}\end{array}$} & \multirow{2}{*}{ 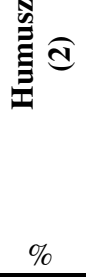 } & \multirow{2}{*}{ 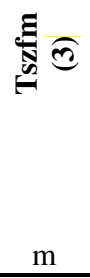 } & \multirow{2}{*}{$\begin{array}{c}\stackrel{0}{0}_{0}^{n} \mathcal{J} \\
\%\end{array}$} \\
\hline & $\begin{array}{c}\text { Homok } \\
(5) \\
2-0,05 \\
\mathrm{~mm}(\%)\end{array}$ & $\begin{array}{c}\text { Iszap } \\
(6) 0,05- \\
0,002 \\
\mathrm{~mm}(\%)\end{array}$ & $\begin{array}{c}\text { Agyag } \\
(7) \\
<0,002 \\
\mathrm{~mm}(\%)\end{array}$ & & & & & & \\
\hline $\begin{array}{l}\text { Szőlö(8) } \\
\text { EOV: }\end{array}$ & 12,1 & 36,2 & 51,8 & 7,1 & 23,6 & 0,36 & 2,5 & 269,8 & 57,7 \\
\hline $\begin{array}{l}546589 \\
175606 \\
\end{array}$ & $\pm 1,3$ & $\pm 2,7$ & $\pm 2,7$ & $\pm 0,0$ & $\pm 6,1$ & $\pm 0,0$ & $\pm 0,5$ & & $\pm 4,6$ \\
\hline $\begin{array}{l}\text { Szántó(9) } \\
\text { EOV: }\end{array}$ & 10,4 & 44,8 & 44,8 & 7,1 & 18,1 & 0,25 & 1,9 & 220,1 & 55,2 \\
\hline $\begin{array}{l}546052 \\
176715\end{array}$ & $\pm 0,8$ & $\pm 1,1$ & $\pm 0,3$ & $\pm 0,0$ & $\pm 1,0$ & $\pm 0,0$ & $\pm 0,1$ & & $\pm 6,28$ \\
\hline $\begin{array}{l}\text { Gyep(10) } \\
\text { EOV: }\end{array}$ & 22,7 & 39,85 & 37,5 & 5,8 & 0,0 & 0,28 & 3,8 & 282,3 & 56,8 \\
\hline $\begin{array}{l}547173 \\
1767120 \\
\end{array}$ & $\pm 0,8$ & $\pm 2,8$ & $\pm 2,3$ & $\pm 0,34$ & & $\pm 0,1$ & $\pm 0,6$ & & $\pm 3,0$ \\
\hline $\begin{array}{l}\text { Erdő(11) } \\
\text { EOV: }\end{array}$ & 15,9 & 55,0 & 29,2 & 5,4 & 0,0 & 0,23 & 3,9 & 284,4 & 59,5 \\
\hline $\begin{array}{l}547150 \\
1767177\end{array}$ & $\pm 0,3$ & $\pm 0,5$ & $\pm 0,3$ & $\pm 0,3$ & & $\pm 0,1$ & $\pm 0,2$ & & $\pm 3,6$ \\
\hline
\end{tabular}


A vizsgálati eredmények alapján megfigyelhetö, hogy az egyes területek között jelentős különbségek vannak. A szemcsefrakciók aránya alapján a szőlöszántó-gyep-erdő sorrendben csökken az agyag- és nő a homoktartalom. A szőlő és a szántó talaja gyengén lúgos és mésztartalma jelentős, míg a gyep és az erdő talaja gyengén savanyú, és mészmentes. A szőlő és a szántó humusztartalma kisebb, mint az erdő és a gyep talaja.

Talajnedvesség változása a különbözö földhasználati rendszerekben és nagyobb csapadékesemények gyakorisága

A vizsgált időszakban több nagyobb mennyiségű csapadékesemény történt, mennyiségüket tekintve a legkiemelkedőbbek a 2016. január 11-i, 11,4 mm napi csapadékösszeggel és 2016. február 3-i, 21,6 mm napi csapadékösszeggel (2. ábra). A vizsgált kisvízgyüjtő domborzata meghatározó szerepet játszott a talajnedvesség alakulásában.

A szőlő, erdő és gyepes mintaterületeken a növényzet vegyes növekedési fázisokban, míg a szántón az öszi búza kezdetleges növekedési fázisban volt.

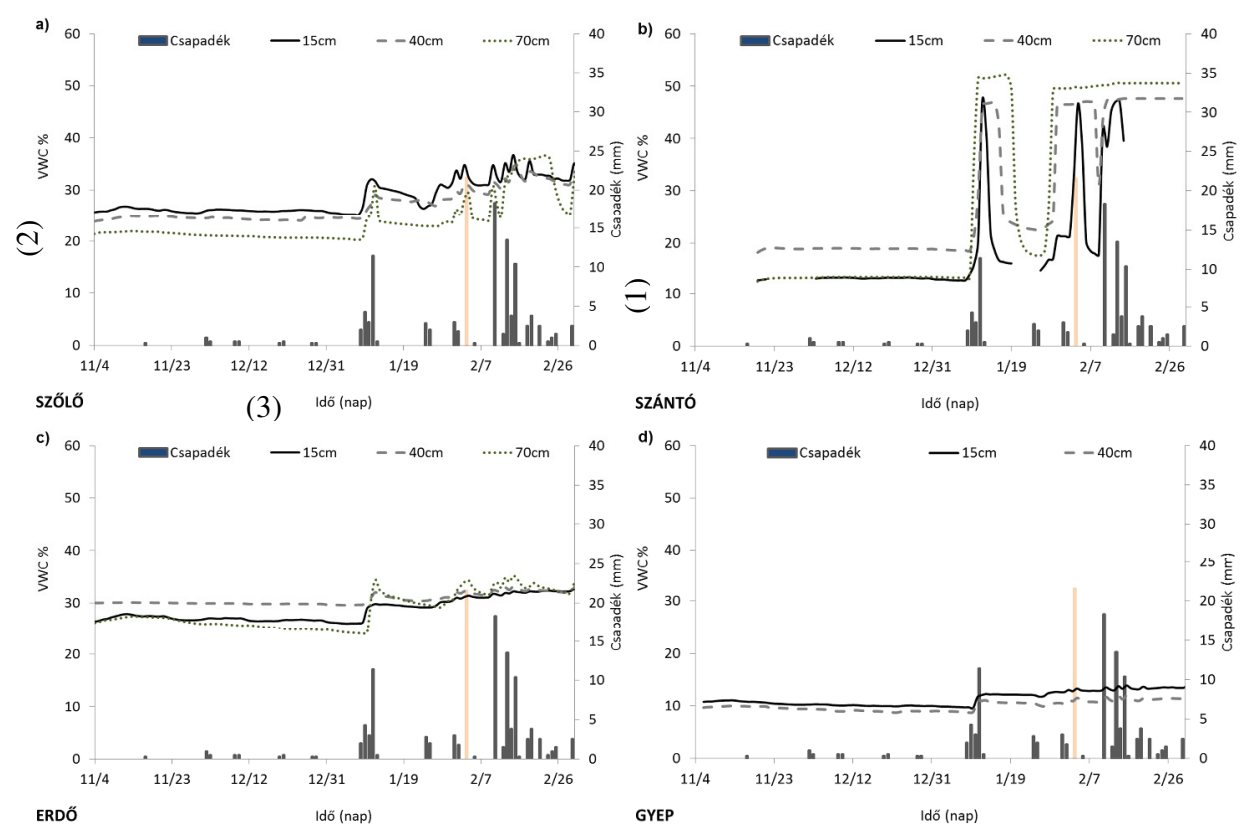

2. ábra

Talajnedvesség és napi csapadékösszeg alakulása 2015.11.04 és 2016.02.29. között különböző földhasználati területeken. Az ábra a) szőlő, b) szántó, c) erdő, d) gyep felszínborítottságú mintaterületeket mutatja. A VWC a talajnedvességet jelöli (v/v\%). 
A 2016. februári, 42 órás kampánymérés idején a legkisebb talajtakarás a szántó területen volt, mivel az elvetett öszi búza ekkor még csak csírázott. Ezt követte az enyhén gyomos állapotú (ősszel a sorközökben feltárcsázott) szőlő, majd a sürübben nőtt cserjés és erdő. A legnagyobb növényborítottság a gyepes területre volt jellemzö, ami a talajnedvességváltozásra erős befolyással bír, viszont az áthulló csapadék mennyiségére nincs hatással.

A szántó mintaterületen nagyobb csapadékesemények alkalmával az alsóbb talajrétegekben víztelítettséghez közeli állapot lépett fel (2.b ábra) amit a porozitás adatok alátámasztanak. Mindemellett feltételezhető, hogy a lehulló csapadék egy része a magasabban fekvő területekröl felszíni vízlefolyással az alacsonyabban fekvő, minimális lejtésű szántó területen gyülemlett fel. A magasabban elhelyezkedő területeken csak a szőlő esetében fordult elő telítettséghez közeli talajnedvesség állapot az altalaj $70 \mathrm{~cm}$-es mélységében (2.a ábra). A mélyebben elhelyezkedő talajrétegek felsőbb rétegekhez viszonyított korábbi telítődésének legvalószínübb okai a talajszerkezet heterogenitása, vagy egy vízzáró réteg közelsége. A talajban lévö törések, állati üregek, repedések mentén történő gyorsabb vízmozgás elősegíti a talajnedvesség mélyebb rétegeibe jutását egy-egy csapadékesemény alkalmával (JARVIS, 2007; HOREL et al., 2014). Az alacsonyan fekvő szántó esetében a vizsgált terület erősen érzékeny felszivárgó belvizekre (RAKONCZAI et al., 2011), egy vízzáró réteg felszínhez való közelsége már kismértékủ csapadék hatására elősegíti a felette lévő talajrétegek telítettségét.

\section{2. táblázat.}

A felszínt elérő esővíz mennyisége és kémhatása a különböző növényborítottságú területeken. * a teljes lehulló csapadékmennyiség értéke.

\begin{tabular}{lcc} 
& $\begin{array}{c}\text { Összes áthullott } \\
\text { csapadék (1) } \\
\text { mm }\end{array}$ & pH \\
\hline Gyep (2)* & 26,25 & - \\
& $\pm 0,15$ & 8,13 \\
\hline Szőló (3) & 23,57 & $\pm 0,25$ \\
\hline Cserjés (4) & $\pm 0,62$ & 8,55 \\
& 20,03 & $\pm 0,02$ \\
\hline Erdó (5) & $\pm 1,71$ & 7,27 \\
& 19,28 & $\pm 0,10$ \\
\hline & $\pm 1,57$ & 7,08 \\
& &
\end{tabular}

A talaj a gyep és az erdő alatt volt a legszárazabb a vizsgált időszak alatt, nagyobb csapadékesemények hatására a talajnedvesség kisebb mértékben változott ezeken a mintaterületeken, mint a szántó és a szőlő területeken. A gyepes és erdős területek agyagban szegényebb, homokosabb talajai (1. táblázat) a talajnedvességet 
kevésbé tudják megtartani, ugyanakkor a csapadék beszivárgását elősegítő szemcseösszetétel hatását a növényzet és a lejtésszög felülírhatja. A víz beszivárgását a talaj hőmérséklete is befolyásolja, azonban ez a hatás számottevően csak fagypont körüli hőmérsékleten érzékelhető (KLIMES-SZMIK, 1978) valamint a hőmérsékleti hatás kevésbé függ a talaj típusától (BOZÓKY-SZESZICH et al., 1963). Ezért valószínü, hogy a vizsgálatunk idején a viszonylag enyhe téli időjárásnak köszönhetően, a nagyobb felszínborítottság (sürü füves terület, illetve avartakaróval fedett erdő talaja) befolyásolhatta leginkább a csapadék talajba való bejutásának sebességét. A gyep esetében nem hagyhatjuk figyelmen kívül a jelentős mennyiségű, a sekély rétegben $(0-5 \mathrm{~cm})$ található gyökértömeget (gyökérnemez) sem. A sürü, hajszálgyökerekben gazdag gyökérhálózat a lehullott csapadékot gyorsabban fel tudja szívni a felszín közeli talajrétegekből, télen azonban a respiráció nem számottevő. Erdősebb területeken a vizet a mélyebben elhelyezkedő gyökerek is adhatják a fák részére (BALDOCCHI et al., 2004), ennek mennyisége azonban a téli időszakban alacsony a tavaszi-nyári időszakhoz viszonyítva (ESSIAMAH \& ESCHRICH, 1986). SURDA és munkatársai (2015) gyepes és mohás vegetációnál vizsgálták a növényzet növekedési fázisai, a vízbeszivárgás, valamint a talaj nedvességtartalma közötti összefüggéseket. A szerzők azt tapasztalták, hogy a vízcseppek penetrációs ideje a növényzet növekedési fázisainak függvényében változik, vagyis a nagyobb növénysürüség hosszabb penetrációs időt eredményez. A sürü, gyepes növényzet hasonlóan az erdős területekhez, az intercepció által lassítja az esőcseppek talajfelszínre, illetve onnan a talaj mélyebb rétegeibe jutását, a nyílt felszínű talajhoz képest (például őszi búza kezdetleges növekedési fázisban).

A 2. táblázatban szereplő csapadékmennyiség-adatok jól szemléltetik az intercepció hatását; a gyephez, mint összes lehullott csapadékmennyiséghez viszonyítva a szőlő esetében $11,37 \%$-kal, a cserjésben 31,05\%-kal, és az erdőben 36,15\%-kal kevesebb esővíz jutott el a talajfelszínig, vagyis a gyeppel, avartakaróval borított, illetve nyílt terepi felszínig).

A növényzet felületén lerakódott anyagok, mint például a szálló porszemcsék, a lehulló csapadék minőségét is befolyásolhatja, mint ahogy azt a 2. táblázat is mutatja. A lehulló tiszta esővíz kémhatása természetes hatások következtében enyhén savas, pH 5,6 (MoORE, 1983; GaLlOWAY et al., 1982), ami lényegesen kisebb, mint a nyílt felszínen, a gyepes területen mért $\mathrm{pH}$ érték. A pH értékekben észlelt különbségek valószínűleg a növényzetre lerakódó majd az eső által lemosodó szennyeződés következménye (STEVENS, 1987). Emellett, a csapadék kémhatását a csapadékesemények gyakorisága és a lehullott csapadék mennyisége is befolyásolja (DAwSON et al., 1977; MOORE, 1983).

A 3. táblázat mutatja, hogy a legnagyobb átmérővel rendelkező esőcseppek a csapadékesemény elején, közvetlenül az első órát követőn hullottak a felszínre. Az intercepció nélküli átlagos esőcsepp átmérők 1,10 és $1,39 \mathrm{~mm}$ között voltak az 5 órás csapadékesemény ideje alatt (1. egyenlet; 3 . táblázat). A növényzeten áthulló esöcseppek mérete és száma a növényzet borítottságától, növényfelépítés szakaszától és levélfelületének méretétől függően tovább változik (NANKO et al., 2006). A téli időszakban a levélzet kevésbé, viszont a növényzet ágrendszere nagyobb mértékben befolyásolja a felszínre (gyeppel, avartakaróval borított, illetve 
nyílt talajfelszínre) jutó csapadék mennyiségét (2. táblázat). A csapadékintenzitás hatását az esőcseppek átlagos átmérőjére a 3. táblázat jól érzékelteti.

\section{3. táblázat.}

Az esőcseppek átlagos átmérőjének $\left(D_{50}\right)$ csapadékintenzitás alapján számolt változása az idő függvényében.

\begin{tabular}{ccccc}
$\begin{array}{c}\text { Idő } \\
\text { 2016.02.03. } \\
\text { (óra) }(\mathbf{1})\end{array}$ & $\begin{array}{c}\text { Átlag } \boldsymbol{T} \\
\left(\mathbf{C}^{\circ}\right)(\mathbf{2})\end{array}$ & $\boldsymbol{\alpha}$ & $\begin{array}{c}\boldsymbol{R}(3) \\
(\mathbf{m m} / \mathbf{r} \mathbf{r a})\end{array}$ & $\begin{array}{c}\boldsymbol{D}_{50} \\
(\mathbf{m m})\end{array}$ \\
\hline $14-15$ & 9,62 & 0,83 & 4 & 1,24 \\
$15-16$ & 9,35 & 0,83 & 6 & 1,39 \\
$16-17$ & 8,32 & 0,80 & 6 & 1,36 \\
$17-18$ & 5,57 & 0,73 & 4 & 1,10 \\
$18-19$ & 4,15 & 0,69 & 1 & 0,69
\end{tabular}

A Csorsza-patakból a Balatonba jutó lebegtetett hordalék időbeni változása jelentős csapadékesemény hatásra

Hosszabb távon vizsgálva, a patak zavarossága és a lehullott csapadék mennyisége között erős korreláció van (3.a ábra).

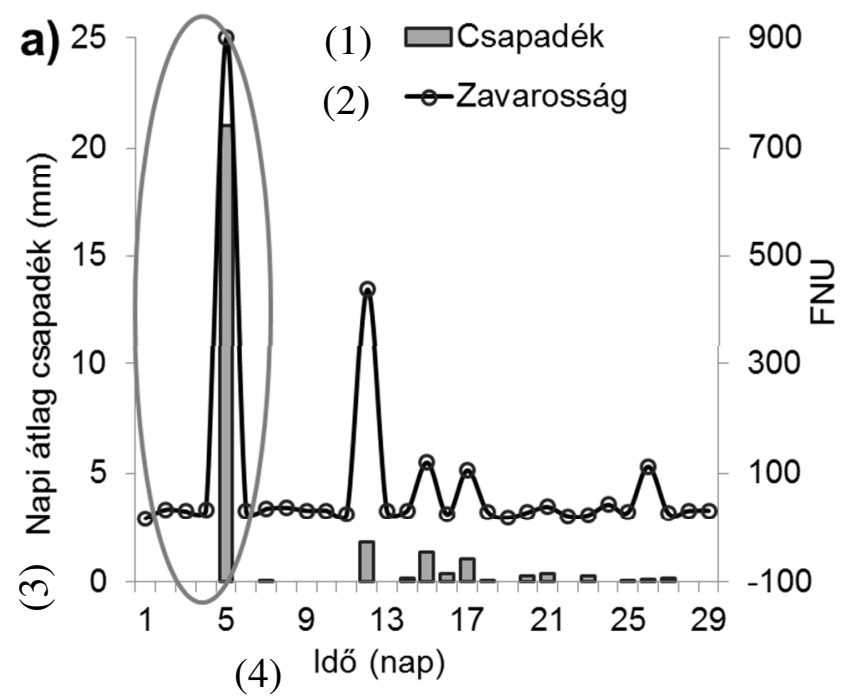

3. a ábra

Csapadékintenzitás és a zavarosság a Csorsza-patakban, csapadékesemény hosszának függvényében, a) esemény utáni napi felbontásban 2016. február 3. és 25 . között, és ... 


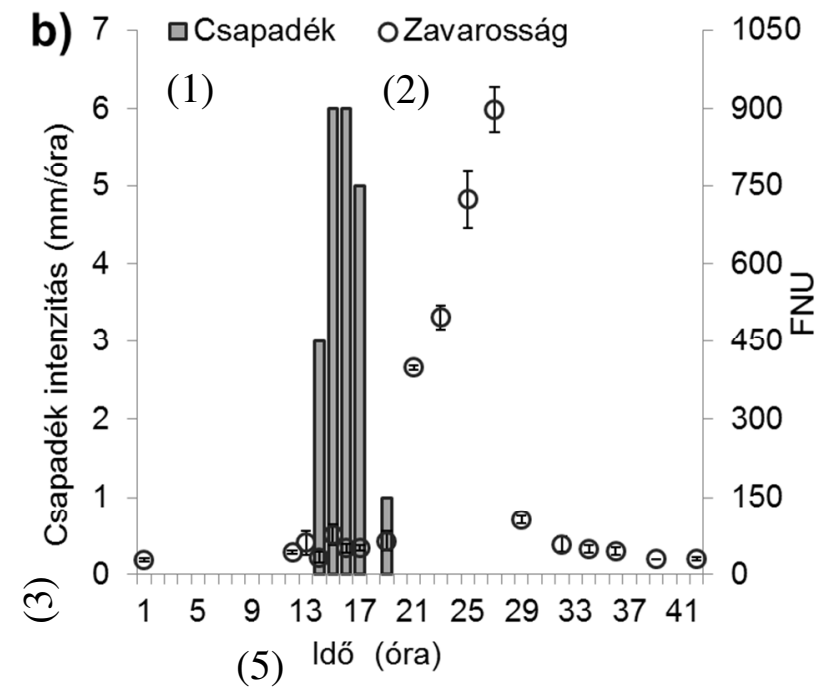

3.b ábra

... csapadékintenzitás és a zavarosság a Csorsza-patakban, csapadékesemény hosszának függvényében, b) esemény alatti órás felbontásban, 2016. február 3-án.

A kis vízgyüjtőterülettel rendelkező patak zavarossága erősen változott a csapadékeseményt követően, viszont rövid időn belül visszatért az eredetihez közeli értékre (13 óra), hangsúlyozva a lebegtetett hordalék, továbbá a megnövekedett vízmennyiség és az általa szállított talajrészecskék, illetve más szennyeződés Balatonba jutásának időszakosságát.

A 3.b ábrán az esőzés intenzitása, illetve a patak zavarosságának alakulása látható a 42 órás mintavétel ideje alatt (2016. február 3). Az ábrán jól látható, hogy 5 és $6 \mathrm{~mm} /$ óra intenzitású csapadék hullott a mintaterületre három órán keresztül. A csapadékesemény gyors lefolyású volt, mely a 3. órát követően erősen mérséklődött, így az $1 \mathrm{~mm} /$ órás intenzitást sem érte el a későbbi órákban. Ezen eseménnyel jól érzékeltethető a vízgyüjtőről a Balatonig jutó talajerodálási folyamat. A kampánymérés 14 . órájában kezdett el esni az eső, ekkor a zavarosság nem volt szignifikánsan eltérő az addig megfigyelt átlagértéktől (3.b ábra) ami a patak hosszának függvénye is. A zavarosság mértéke a kísérlet 19. órájáig viszonylag stabil volt, ahol az FNU zavarossági értékek 32,43 és 75,53 között mozogtak. A kísérlet 21. órájában a vízgyüjtő területén hullott nagy mennyiségủ csapadék az elmozdított talajszemcsék megnövekedett mennyiségével egyetemben elérte a patak balatoni torkolatát. Az FNU értékek hirtelen több, mint hatszorosára nőttek az addig megfigyeltekhez képest, miközben a lehulló csapadék intenzitása

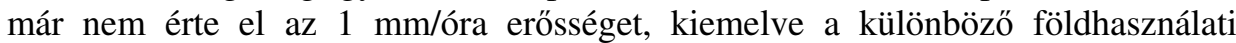
területekről a 8 km hosszúságú patakba lefolyó hordalék területi és területhasználati heterogenitását. CORRELL et al. (1999) legelő, erdő és szántó területekről származó lebegtetett hordalékvizsgálatokat hasonlított össze, ahol téli időszakban átlag háromszor több teljes lebegtetett hordalék került a folyóba szántó területről az 
erdőhöz képest, és majdnem kétszeres mennyiség a legelőhöz viszonyítva. A vizsgált időszak 27. órájában történt a legnagyobb mennyiségben a talajszemcsék kimosódása. A kísérlet 34. órájában a Csorsza-patakban levonuló lebegtetett hordalék mennyisége visszaállt a csapadékesemény elöttihez hasonló értékre, azaz az elmozdított talajszemcsék mennyiségének jelentős megemelkedése 13 órán keresztül tartott. A csapadékesemény intenzitása és időtartama erősen befolyásolta a patakba jutó lebegtetett hordalék mennyiségét, valamint annak időbeni eloszlását. A csapadékesemény kezdetétôl az elmozdított talajszemcsék 7 óra alatt jutottak el a mérési helyhez, a torkolathoz. Mindazonáltal a jelentősen megemelkedett zavarosság sokkal tovább volt érzékelhető, mint a legintenzívebb csapadékhullás időszaka (3 óra), ami a vízgyüjtőn belül a vízvisszatartás időszakát (retenciós idő) befolyásoló tényezők összetettségére hívja fel a figyelmet.

A csapadékintenzitás és a zavarosság időbeni alakulásának összevetése alapján elmondható, hogy a vízgyüjtő reakcióideje az erodálódott talajszemcsék szempontjából körülbelül 7 óra.

\section{Összefoglalás}

A vizsgálat 42 órája alatt (2016. február 3-4.) és az elötte lévő öt hónapban összesen négy nagyobb mennyiségü csapadékesemény történt a Csorsza-patak vízgyüjtő területén. A vizsgált esőzés időszakában 21,6 mm csapadékmennyiség hullott összesen a vízgyüjtő területére 5 órás intervallumban. A csapadékesemény első órájában a patak zavarosság értéke majdnem megduplázódott, viszont így is viszonylag alacsony szinten maradt a későbbiekben mért értékekhez viszonyítva. $\mathrm{Az}$ esőzés kezdetét követő 7 . órában emelkedett meg jelentősen a zavarosság mértéke, több mint 14-szeresére, a 13-14. órában pedig 34-szeresére nőtt a vizsgálat elötti naphoz viszonyítva. A Csorsza-patak zavarosságának nagysága nem sokkal a tetőzést követően nagy mértékben lecsökkent, 13 órával később pedig hasonló értékeket mutatott, mint a vizsgálat előtti esőzés nélküli időszakban.

A nagyobb esőzések alkalmával az alacsonyabb területeken fekvő, minimális lejtésú szántó esetében telítettséghez közeli talajnedvesség-tartalom volt megfigyelhetö, míg a legkisebb talajnedvesség-tartalom ingadozás az esőzést követően a gyepes és az erdős területekre volt jellemző.

A jelen vizsgálatban összegyüjtött adatok alapján a Csorsza-patakból a Balatonba bekerülő talajhordalék mennyisége a téli időszakban, az erozív esőzések gyakoriságának ismeretében könnyebben és pontosabban becsülhető. Annak érdekében, hogy az éves átlag lebegtetett hordalék mennyiségének a becslését pontosabban el tudjuk végezni, több időszakos mérésre volna szükség.

Munkánkat az OTKA K-101065 projekt, az OTKA PD-116157 és OTKA PD-116084 kutatási projekt, valamint a Bolyai János Kutatási Ösztöndíj támogatta. Külön köszönet Mózes Mariann és Bányász Ágnes részére a laboratóriumi vizsgálatokban nyújtott segítségükért, valamint Szegvári Győző és kollégáinak a zánkai vízminták gyűjitésében való hatalmas segítségükért. 
Kulcsszavak: talajszerkezet; talajnedvesség; csapadék beszivárgás; Balaton;

\section{Irodalom}

ALEXANDER, L.V. 2016. Global observed long-term changes in temperature and precipitation extremes: A review of progress and limitations in IPCC assessments and beyond. Weather and Climate Extremes. 11. 4-16.

BALDOCCHI, D.D., Xu, L. \& KIANG, N. 2004. How plant function-type, weather, seasonal drought, and soil physical properties alter water and energy fluxes of an oak-grass savanna and an annual grassland. Agricultural and Forest Meteorology. 123. 13-39.

BozóKY-SZESZich, K., KLIMES-SZMiK, A., \& SzOLNOKY, Cs. 1963. A fagyott talajok vízáteresztésének laboratóriumi vizsgálata. Hidrológiai Közlöny. 43. (6) 509-518.

BRANDT, S.C.J. 1989. The size distribution of throughfall drops under vegetation canopies. Catena. 16. 507-524.

Castillo, V.M., Gómez-Plaza, A. \& Martínez-Mena, M. 2003. The role of anecedent soil water content in the runoff response of semiarid catchments: a simulation approach. Journal of Hydrology. 284. 114-130.

CORINE Felszínborítási Adatbázis (CLC50) 2006. Földmérési és Távérzékelési Intézethttp://fish.fomi.hu/letoltes/nyilvanos/corine/clc50_referencia_cikk.pdf

CORRELL, D., JORDAN, T.E. \& WELLER, D.E. 1999. Precipitation effects on sediment and associated nutrient discharges from Rhode River watersheds. Journal of Environmental Quality. 28. 1897-1907.

Cruz-Martinez, K., Suttle, K.B., Brodie, E.L., Power, M.E., Andersen, G.L. \& BANFIELD, J.F. 2009. Despite strong seasonal responses, soil microbial consortia are more resilient to long-term changes in rainfall than overlying grassland. The ISME Journal. 3. 738-744.

CsORBA, SZ., FARKAS, Cs. \& BIRKÁS, M. 2011. Kétpórusú víztartóképesség-függvény a talajművelés-hatás kimutatásában. Agrokémia \& Talajtan. 60. 325-342.

DAWSON, G.A. 1967. Ionic composition of rain during sixteen convective showers Atmospheric Environment. 12. 1991-1999.

Dolman, A.J. 1987. Summer and winter rainfall interception in an oak forest. Predictions with an analytical and a numerical simulation model. Journal of Hydrology. 90. 1-9.

DöVÉNYI, Z. (Szerk.), 2010. Magyarország kistájainak katasztere. MTA Földrajztudományi Kutatóintézet. Budapest.

ESSIAMAH, S. \& ESCHRICH, W. 1986. Water uptake in deciduous trees during winter and the role of conducting tissues in spring reactivation. IAWA Bulletin. 7. 31-38.

Farkas, Cs., Beldring, S., Bechmann, M. \& Deelstra, J., 2013. Soil erosion and phosphorus losses under variable land use as simulated by the INCA-P model. Soil Use and Management. 29(s1). 124-137.

FARKAS, Cs., Gelybó, Gy., BAKACSI, Zs., Horel, A., Hagyó, A., Dobor, L., Kása, I. \& TóTH, E. 2014. Impact of expected climate change on soil water regime under different vegetation conditions. Biologia. 69.1510-1519.

FAŠKO, P., LAPIN, M. \& PECHO, J., 2008. 20-year extraordinary climatic period in Slovakia. Meteorol. Časopis. 11. 99-105. 
Galloway, J.N., LiKens, G.E., KeEnE W.C. \& MiLler, J. M. 1982. The composition of precipitation in remote areas of the world, J. Geophys. Res., 87. 8771-8786.

Horel, A., Lichner, L., Alaoui, A., CZAChor, H. \& TOTH, E. 2014. Transport of iodide in structured clay-loam soil under maize during irrigation experiments analyzed using HYDRUS model. Biologia. 69. 1531-1538.

Horel, A., Lichner, L., Kodesova, R. \& SteKaUEROVA, V. 2015a. Effects of land use and irrigation intensity on the transport of iodide in structured clay loam soil. Agrokémia \& Talajtan. 64. 391-402.

Horel, A., Tóth, E., Gelybó, Gy., KÁsA, I., BAKacsi, Zs. \& FARKAS, Cs. 2015b. Effects of land use and management on soil hydraulic properties. Open Geosciences. 1.742-754.

IPCC. 2007. Climate Change. Impacts, adaptation and vulnerability. In: Parry M.L., Canziani O.F., Palutikof J.P., van der Linden P.J. \& Hanson C.E. (eds), Contribution of Working Group II to the Fourth Assessment Report of the Intergovernmental Panel on Climate Change. Cambridge University Press, Cambridge, 976 pp.

JARVIS, N.J. 2007. A review of non-equilibrium water flow and solute transport in soil macropores: principles, controlling factors and consequences for water quality. European Journal of Soil Science. 58. 523-546.

Jordán, Gy., van Rompaey, A., Szilassi, P., Csillag, G., Mannaerts, C. \& WOLDAI, T. 2005. Historical land use changes and their impact on sediment fluxes in the Balaton basin (Hungary). Agriculture, Ecosystems and Environment. 108. 119-133.

KAY, B.D. 1990. Rates of change of soil structure under different cropping systems. Advances in Soil Science. 12. 1-51.

Keggenhoff, I., ElizbarashVILI, M., AmiRI-FARAHAni, A. \& KING, L. 2014. Trends in daily temperature and precipitation extremes over Georgia, 1971-2010. Weather and Climate Extremes. 4. 75-85.

KERÉNYI, A. 1984. A csepperózió hatása a homokszemcsék méret szerinti differenciálódására. Agrokémia \& Talajtan. 33. 63-74.

KERÉNYI, A. 1986. Az iniciális erózió laboratóriumi vizsgálata homokon és szerkezetes talajon. Agrokémia és Talajtan. 35. 18-38.

KLEIN TANK, A.M.G. \& KÖNNEN, G.P. 2003. Trends in indices of daily temperature and precipitation extremes in Europe, 1946-99 Journal of Climate 16. 3665-3680.

KLIMES-SzMIK, A. 1978. A talaj lepusztulásának fizikai tényezői. Agrokémia és Talajtan 28. (1-2) 273-284.

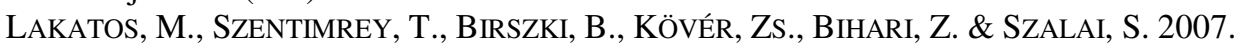
Changes of temperature and precipitation extremes following homogenization. Acta Silv. Lign. Hung. 3. 87-95.

LiCHNER, L'., DUŠEK, J., DEKKER, L. W., ZHUKOVA, N., FAŠKO, P., HOLKO, L. \& Š́́r, M., 2013. Comparison of two methods to assess heterogeneity of water flow in soils. J. Hydrol. Hydromech. 61. 299-304.

LIU, H., LEI, T.W., ZHAO, J., YUAN, C.P. \& QU, L.Q. 2011. Effects of rainfall intensity and antecedent soil water content on soil infiltrability under rainfall conditions using the run off-on-out method. Journal of Hydrology. 396. 24-32. 
Medeiros, P.H.A., GÜntner, A., Francke, T., Mamede, G.L. \& DE AraúJo, J.C. 2010. Modelling spatio-temporal patterns of sediment yield and connectivity in a semi-arid catchment with the WASA-SED model, Hydrological Sciences Journal. 55. 636-648.

Mohammad, A.G. \& ADAM, A.A., 2010. The impact of vegetative cover type on runoff and soil erosion under different land uses. Catena. 81. 97-103.

MOORE, I.D. 1983. Throughfall pH: effect of precipitation timing and amount. Water Resources Bulletin. 19.961-965.

MorgAn, R.P.C., 1978. Field studies of rainsplash erosion. Earth Surface Processes. 3. 295-299.

MorGAN, R.P.C. \& DUZANT, J.H. 2008. Modified MMF (Morgan-Morgan-Finney) model for evaluating effects of crops and vegetation cover on soil erosion. Earth Surface Processes and Landforms. 32. 90-106.

MSZ-08-0205:1978, A talaj fizikai és vízgazdálkodási tulajdonságainak vizsgálata.

MSZ-08-0206-2:1978, A talaj egyes kémiai tulajdonságainak vizsgálata. Laboratóriumi vizsgálatok. (pH-érték, szódában kifejezett fenolftalein lúgosság, vízben oldható összes só, hidrolitos és kicserélődési aciditás).

MSZ-08-0210:1977, A talaj szerves szén tartalmának meghatározása.

MülLER, K., STENGER, R. \& RAHMAN, A. 2006. Herbicide loss in surface runoff from a pastoral hillslope in the Pukemanga catchment (New Zealand): Role of pre-event soil water content. Agiculture, Ecosystetm and Environment. 112. 381-390.

NANKO, K., HotTA, N. \& SUZUKI, M. 2006. Evaluating the influence of canopy species and meteorological factors on throughfall drop size distribution. Journal of Hydrology. 329. 422-431.

Nguyen, H.L., Leermakers, M., OsÁn, J., TÖRÖK, S. \& BAeYens, W. 2005. Heavy metals in Lake Balaton: water column, suspended matter, sediment and biota. Science of the Total Environment. 340. 213-230.

PILCH, M. \& ERDMAN, C.A., 1987. Use of breakup time data and velocity history data to predict the maximum size of stable fragments for acceleration-induced breakup of liquid drop. International Journal of Multiphase Flow. 13. 741-757.

RAJKAI, K., 1988. A talaj víztartóképessége és egyéb tulajdonságok összefüggésének vizsgálata. Agrokémia és Talajtan. 36-37. 15-30.

RAJKAI, K., 2012. Talajfizika. Agrokémia és Talajtan. 65. Supplementum, 47-92.

RAKONCZAi, J., FARSANG, A., MEZÖSI, G. \& GÁL, N. A belvízképződés elméleti háttere. Földrajzi Közlemények. 135. 339-349.

RÜGner, H., Schwientek, M., Beckingham, B., KuCH, B. \& Grathwohl, P. 2013. Turbidity as a proxy for total suspended solids (TSS) and particle facilitated pollutant transport in catchments. Environmental Earth Sciences. 69. 373-380.

SHAXSON, F. \& KASSAM, A. 2015. Soil erosion and conservation. Agriculture for Development, 21. szerk.: HARDing, P., WARHAM, E., Sims, B., KASSAM, A., Hawtin, G., Brammer, H., Stewart, A., Malins, J., Virgo, K. 2015. Tropical Agriculture Association, Egyesült Királyság. 21-25.

Stenger-KovÁcs, CS., Bíró, P., SORÓcZKI-Pintér, É., KIRÁlyKuTI, I. \& PADISÁK, J. 2008. A Balaton befolyóinak ökológiai állapota a bevonatalkotó kovaalgák alapján. Hidrológiai Közlöny 88. (6). 192-195. 
STEVENS, P.A. 1987. Throughfall chemistry beneath Sitka spruce of four ages in Beddgelert Forest, North Wales, UK. Plant and Soil. 101. 291-294.

Surda, P., Lichner, L., NAGY, V., Kollar, J., IOvino, M. \& Horel, A. 2015. Effects of vegetation at different succession stages on soil properties and water flow in sandy soil. Biologia, 70. 1-6.

SZILASSI, P., JORDAN, Gy., VAN ROMPAEY, A. \& CSILlaG, G., 2006. Impacts of historical land use changes on erosion and agricultural soil properties in the Kali Basin at Lake Balaton, Hungary. Catena. 68. 96-108.

SzIVÁK, I. \& MóRA, A. 2009. Occurrence of rare caddisfly (Trichoptera) species at the catchment area of Lake Balaton. (Ritka tegzesfajok (Trichoptera) elöfordulása a Balaton vízgyüjtőjén. Acta Biologica Debrecina. Supplementum oecologica hungarica. 20. 219-230.

XiAO, Q., McPherson, E.G., Ustin, S.L., GRISMER, M.E. \& SimPson, J.R., 2000. Winter rainfall interception by two mature open-grown trees in Davis, California. Hydrological Processes. 14. 763-784.

ZANCHI, C. \& TORRI, D., 1980. Evaluation of rainfall energy in Central Italy. In: De Boodt, M., Gabriels, D. (eds). Assessment of erosion. Wiley, Chichester, pp. 133142.

ZiADAT, F.M. \& TAIMEH, A.Y., 2013. Effect of rainfall intensity, slope, land use and antecedent soil moisture on soil erosion in an arid environment. Land Degradation \& Development. 24. 582-590.

\title{
Investigating the effect of winter rainfall events on hydrological processes in the catchment area of the Csorsza stream
}

\author{
A. Horel ${ }^{1}$, Z. BAKACSI ${ }^{1}$, M. DenCsö ${ }^{1}$, C. FARKAS ${ }^{1,2}$, G. GelYBó $^{1}$, I. KÁSA ${ }^{1}$, \\ E. TóTH ${ }^{1}$, S. MOLNÁR ${ }^{1}$ and S. Koós ${ }^{1}$ \\ ${ }^{1}$ Institute for Soil Science and Agricultural Chemistry, Centre for Agricultural Research, \\ Hungarian Academy of Sciences, Budapest \\ ${ }^{2}$ NIBIO, Norwegian Institute of Bioeconomy Research, Ås
}

\section{Summary}

The amount of suspended sediments leaving the Csorsza catchment area over time was investigated on the basis of turbidity measurements. These were taken at a distance of approximately $3.4 \mathrm{~km}$ from the vegetative study sites daily until the start of the erosive rain event, and every one or two hours during and after the event for a total of 42 hours. Soil water contents and soil temperatures were continuously measured at three depths $(15,40$ and $70 \mathrm{~cm}$ below the surface), while overall weather data were obtained either from local measurements at the sites (for precipitation) or from meteorological stations close to the pilot area (for other meteorological variables). During an erosive rainfall event (precipitation $=21.6$ $\mathrm{mm} ; 3$ Feb. 2016), a rain gauge was placed at the study site to measure precipitation 
intensities. During the 3-hour heavy rain event, precipitation rates of 5, 6 and 6 $\mathrm{mm} / \mathrm{h}$ were recorded. Water turbidity measurements showed a good correlation with the amount of precipitation. During the erosive precipitation event, water turbidity increased considerably to approximately 6 times the background value (from 30-70 FNU to 300 FNU, where FNU stand for Formazin Nephelometric Unit) within two hours of the rain event. The greatest turbidity ( $900 \mathrm{FNU})$ was measured 6 hours after the initial spike; but 5 hours after the peak the measured turbidity values were already similar to values prior to the precipitation event.

Key words: erosive rainfall, river turbidity, FNU, soil moisture, small catchment

Table 1. Soil properties in the $2-10 \mathrm{~cm}$ soil layer in different agricultural areas. (1) Particle composition (3 fractions). (2) Organic matter. (3) Height above sea level. (4) As a \% of saturated soil moisture content. (5) Sand. (6) Silt. (7) Clay. (8) Vineyard. (9) Arable. (10) Grassland. (11) Forest.

Table 2. Quantity and $\mathrm{pH}$ of rainwater reaching the soil surface on areas with different plant cover. *Total rainfall quantity. (1) Total rainfall quantity. (2) Grassland. (3) Vineyard. (4) Shrubland. (5) Forest.

Table 3. Change in the mean diameter of raindrops $\left(\mathrm{D}_{50}\right)$ calculated on the basis of rainfall intensity as a function of time. (1) Time on 3 Feb. 2016 (hourly intervals between 2 and $7 \mathrm{pm}$ ). (2) Mean temperature. (3) Rate ( $\mathrm{mm} / \mathrm{h}$ ).

Figure 1. Land-use forms and sampling sites on the sampling area of the Csorsza catchment area (Zánka, Tagyon, Szentantalfa and neighbouring areas) in the Balaton Hills (source: CORINE, 2006).

Figure 2. Changes in soil moisture and daily precipitation sum between 4 Nov. 2015 and 29 Feb. 2016 on areas with different land uses (a. vineyard, b. arable, c. forest, d. grassland). (1) Precipitation. (2) Volumetric soil water capacity. (3) Time (days).

Figure 3. Rainfall intensity and turbidity in the Csorsza stream as a function of the duration of the rainfall event. a) On a daily basis after the event, between 3 and 25 Feb. 2016; b) On an hourly basis during the event on 3 Feb. 2016. (1) Rainfall. (2) Turbidity. (3) Daily mean rainfall. (4) Time (days). (5) Time (hours). 